\title{
PRODUCTION OF BREAD WITH EGGSHELL POWDER AND THE INCREASE OF CALCIUM CONTENT IN THE BODY
}

\author{
Karen Aquipucho $^{1}$, Maria Quispe ${ }^{1 凶}$, Omar Bellido $^{1}$, Juan Zegarra ${ }^{1}$ \\ ${ }^{1}$ Faculty of Processes, Universidad Nacional de San Agustín de Arequipa - Calle Santa Catalina 117, \\ Cercado, Perú \\ ${ }^{\bowtie}$ kaquipucho@unsa.edu.pe \\ https://doi.org/10.34302/crpjfst/2020.12.1.8 \\ Article history: \\ Completed by editor \\ Keywords: \\ Assimilation; \\ Bread, \\ Calcium; \\ Eggshell; \\ Substitution.

\begin{abstract}
Calcium is the most abundant mineral in the body. An inadequate intake of this mineral can cause problems in several vital processes. Eggshell powder is a rich source of calcium that has been shown to have positive effects on bone metabolism. However, the eggshell is classified as a waste material by the food industry, therefore it is not used despite having different properties, its calcium content being one of the most important. The aim of the present investigation was to produce bread using eggshell powder as the raw material in order to develop a bread product rich in calcium. Also, to determine the increase of the calcium content in the body by means of biological analysis. The investigation started with the production of eggshell powder (EP) and the determination of its calcium content by atomic absorption. Then it was replaced in 3 different percentages $(10 \%, 15 \%$ and $20 \%)$ in addition to a blank sample $(0 \%)$ to compare the results. The methodology included the conduct of the biological study, where the substitution at $10 \%$ obtained higher percentage of assimilation $(9.19 \%)$ compared to $15 \%$ and $20 \%$ which were $6.87 \%$ and $4.35 \%$ respectively. Proximal, mineral $(\mathrm{Ca})$ and microbiological evaluations (molds) of the bread were performed after obtaining the optimal substitution. The results were obtained: humidity $(23.8 \%)$, ash $(5.24 \%)$, fat $(3.83 \%)$, proteins $(9.25 \%)$, fiber $(2.10 \%)$, carbohydrates $(55.78 \%)$, kilocalories $(295.79 \mathrm{KJ})$ and calcium $(29.47 \mathrm{mg} / \mathrm{g})$. Finally, the microbiological analysis showed
\end{abstract} \\ harmlessness in bread.
}

\section{Introduction}

Calcium $(\mathrm{Ca})$ is the most abundant divalent cation in the human body. It constitutes between $1.5-2.0 \%$ of the body's total weight. More than $99 \%$ of the body's calcium is found in the skeleton. It occupies a central place in biological systems and is responsible, together with other elements, for structural functions affecting the skeleton and soft tissues, and for regulatory functions such as neuromuscular transmission of chemical and electrical stimuli, the secretion of cells, blood clotting, oxygen transport, and enzymatic activity (Valdés, 2009).
Additionally, a hen's eggshell is an excellent natural source of calcium, consisting of $96 \%$ calcium carbonate (Alais et al., 1990). However, the eggshell is commonly considered a waste. On the other hand, it is commonly consumed by people with scarce resources, those who, in some cases, say they prepare the powdered shell in different homemade solutions such as milk, orange juice or lemon, as well as in vinegar (5\% acetic acid) or in soup (hot water). Therefore, a study that supports the use of the common eggshell as a source of calcium and as the use of a waste would be very useful and applicable (Gómez, 2011). 
Roverský et al. (2003) also note that eggshell powder is a natural source of calcium with positive effects on bone metabolism. In addition, different studies have shown that eggshell powder has positive antirachitic effects in rats and humans.

To provide consumers with more opportunities to increase their calcium intake without resorting to supplementation, manufacturers in the United States are recommended to fortify foods and beverages with calcium if certain criteria are met: the food should be commonly consumed. The additional ingredient compatible with the product must be added, and the technology to strengthen the food must be simple, safe and cost effective (Nollet and Toldrá, 2012). In addition, fortification with calcium has been shown to be an economical way to obtain additional calcium (Keller et al., 2002). Moreover, the human body cannot produce adequate amounts of calcium without external support. Additionally, calcium is daily lost through hair, skin, nails, sweat, urine, and feces. This loss of calcium must be replaced, or the body will take calcium from the bones to perform other functions (Kessenich, 2008).

It is important to highlight that bread is one of the staple foods in many countries of the world. Currently, the consumption of bread and bakery products made from refined wheat flour is often the usual trend. However, this flour is characterized by a limited nutritional value (Isserliyska et al., 2001).

In the present, different food products for children are being developed, which are mainly characterized as fortified and nutritious products. Within them we can find bakery products made by replacing wheat flour with flour of tubers, of cereals or of native grains, which increases their nutritional value (Obrego et al., 2013).

Therefore, the present study aimed to investigate the increase of calcium content in the body through biological tests with mice.

\section{Materials and methods}

\subsection{Obtaining eggshell powder}

Eggshells were collected from different sources such as restaurants, dealerships, bakeries, food trucks, etc. They were washed and disinfected with a 100 ppm sodium hypochlorite concentration for $5 \mathrm{~min}$, according to tests carried out for validation by a HACCP system in a Food Dealer audited by SMC Slovensko (The Mediterranean Certification Society) in 2018 . Next they were dried at $120^{\circ} \mathrm{C}$ for 60 min based by preliminary tests. Then the shells were ground and passed through a mesh sieve for $10 \mathrm{~min}$ with an opening of $106 \mu \mathrm{m}$ based by preliminary tests. The calcium content was then determined by atomic absorption.

\subsection{Bread making}

The method used for the production of the product is the direct method. The loaves were prepared according to the standardized formulation with a slight modification of Mesas and Alegre (2002). The wheat flour was replaced by eggshell powder (EP) in 3 different percentages which were $10 \%(\mathrm{~F} 1), 15 \%(\mathrm{~F} 2)$, and $20 \%(\mathrm{~F} 3)$, these were compared with a blank sample with $0 \%$ (F0) EP substitution. The kneading lasted $5 \mathrm{~min}$. and $50 \mathrm{gr}$ were weighed for each bread. The bread was baked at $180^{\circ} \mathrm{C}$ for 15 minutes. The loaves were then removed, cooled and stored for further study.

\subsection{The Biological Analysis \\ 2.3.1. Animals}

Fifteen (15) albino male mice (Mus musculus) of Balb/c/CNPB strain of experimentation were selected for the investigation at an age of 35 to 38 days old, with a weight in the range of 19 to $22 \mathrm{~g}$. They were divided into five groups (samples in triplicate) distributed as follows:

One standard group (GP)

One white group (GB)

Three experimental groups (GE10, GE15 and GE20)

After two weeks of adaptation, in which the mice were fed a standard maintenance feed for rodents $(1152.09 \mathrm{mg} \mathrm{Ca} / 100 \mathrm{~g})$, the standard 
group was analyzed to know the initial conditions of calcium in their bodies. It should be noted that each rodent was in a cage with its own drinking trough and feeder, thus avoiding aggression and injuries between them.

\subsubsection{Diet}

The white group (GB) and the three experimental groups (GE10, GE15 and GE20) received food orally "ad libitum" for 28 days, the difference was the calcium content in the food supplied. The white group's food was bread with a conventional formulation (F0) containing $0.32 \mathrm{mg} \mathrm{Ca} / \mathrm{g}$ of bread, while the different formulations: Fp1, Fp2, Fp3 contained 29.94 $\mathrm{mg}, 44.75 \mathrm{mg}$ and $59.55 \mathrm{mg}$ of calcium per gram of bread respectively.

\subsubsection{Environmental conditions}

The environmental conditions in which the animals were kept throughout the experiment were constant, 12 light hours and 12 dark hours in a temperature range between $20^{\circ} \mathrm{C}$ to $25^{\circ} \mathrm{C}$ (Fuentes et al., 2008).

\subsubsection{Cleaning up}

The cages were cleaned and disinfected 3 times a week. The cages were washed using detergent and a brush, then they were disinfected with $0.5 \%$ sodium hypochlorite. In the same way the plates containing rodent feces were cleaned. They were left to breathe for $5 \mathrm{~min}$ so that the chemical used was volatilized.

\subsubsection{Collection of data and samples}

During the time of the study the amount of food ingested was weighed daily and the variation in the animals' body weight was measured weekly. A precision scale was used for these measures.

\subsubsection{The slaughter}

The experimental protocol to which the animals were subjected was designed according to the guidelines proposed in the "Guide for the management and care of laboratory animals: Mouse", which exists in Peru approved by the Resolution N³09-2008-J-OPE/INS.

After 28 days of experimentation, rodents were killed by inhalation of chloroform. The animals were placed in a glass bell containing the chemical, with the lid closed. After 30 to 50 seconds the animals were immobilized. To ensure the animal's death you should wait at least 30 seconds after its last breath. (Servicio de Experimentación Animal, 2005).

\subsubsection{Determination of Calcium}

Calcium was determined by the atomic absorption method.

\subsection{Optimal product analysis \\ 2.4.1. Proximate composition}

The proximal composition of the optimal product was determined. Humidity by the NTP 209.085 method, ash by the 2.173 method of AOAC , fat by the 209.093 method, proteins by the 2.057 method of AOAC, fiber by the NTP 209.074 method and carbohydrates by the 31.043 method of the AOAC.

\subsubsection{Microbiological analysis}

Mould count: ICMSF Volume I, 2nd. Edition, Part II, Method I, p. 166-167.

\subsubsection{Calcium content of the optimal product}

Calcium content was determined by atomic absorption.

\subsection{The Statistical Analysis}

The collected data were statistically evaluated by a variance analysis (ANOVA) and the Tukey test with a reliability level of $95 \%$, using the statistical software Minitab 18.

\section{Results and discussions}

\subsection{Calcium content in eggshell powder}

The calcium content in the eggshell powder turned out to be $394.58 \mathrm{mg} / \mathrm{g}$, this high calcium content was due to the calcium carbonate content present in the composition of the flour studied.

Brun et al. (2013) found that a hen's eggshell has a high calcium content of $381 \pm 89 \mathrm{mg} \mathrm{Ca} / \mathrm{g}$ of eggshell, content similar to that written by Bartter et al. (2018) who indicate that the eggshell contains $380 \mathrm{mg} \mathrm{Ca} / \mathrm{g}$ of calcium. Likewise, Schaafsma et al. (2000) found 385 to $401 \mathrm{mg} / \mathrm{g} \mathrm{Ca}$ in the eggshell, depending on its 
origin. These values are similar to those obtained in this work.

\subsection{Biological Analysis}

\subsubsection{Food intake}

The food intake for the white group (GB) and the experimental groups (GE10, GE15 and GE20) was $44.98 \pm 2.48 \mathrm{~g} /$ week.

The intake was constant and equivalent throughout the duration of the treatment, as shown in table 1.

Table 1. Data on food intake during the treatment period

\begin{tabular}{|c|c|c|c|c|c|}
\hline \multirow{2}{*}{ Groups } & \multicolumn{4}{|c|}{ Weeks } & \multirow{2}{*}{$\begin{array}{c}\text { Average } \\
\text { (g) }\end{array}$} \\
\cline { 2 - 5 } & 1 & 2 & 3 & 4 & 44.49 \\
\hline GB & 35.45 & 40.22 & 49.89 & 44.42 & 44.46 \\
\hline GE10 & 42.77 & 48.77 & 48.46 & 37.96 & 47.46 \\
\hline GE15 & 42.07 & 48.13 & 50.70 & 48.93 & 43.04 \\
\hline GE20 & 37.61 & 43.39 & 50.17 & 40.99 & 42.50 \\
\hline
\end{tabular}

Note: GB = White group, GE10 = Experimental group of $10 \%$ substitution, GE15 = Experimental group of 15\% substitution, GE20 = Experimental group of 20\% substitution.

According to Fuentes et al. (2008), laboratory mice had a daily consumption of 3 to 6 grams of food, which means that they had a consumption between 21 and $42 \mathrm{~g} /$ week.

\subsubsection{Total Body Weight}

The variation of the animals' body weight for each experimental group and during the 4 weeks of treatment is shown in table 2 .

Table 2. Variation of the body weight of the mice during the experimental time

\begin{tabular}{|c|c|c|c|c|c|}
\hline \multirow{2}{*}{ Groups } & \multicolumn{5}{|c|}{ Weeks (g) } \\
\cline { 2 - 6 } & 0 & 1 & 2 & 3 & 4 \\
\hline GB & 26.07 & 29.53 & 31.13 & 33.23 & 33.40 \\
\hline GE10 & 30.85 & 30.85 & 32.23 & 33.50 & 31.83 \\
\hline GE15 & 27.70 & 28.80 & 31.67 & 32.50 & 31.14 \\
\hline GE20 & 24.03 & 24.03 & 24.67 & 26.80 & 26.90 \\
\hline
\end{tabular}

The white group (GB) has a greater increase in body weight. In addition, a slight weight gain is observed in the experimental groups with calcium-rich diets (GE10, GE15 and GE20).
However, these values are not significantly different ( $p>0.05)$.

In the same way as indicated by different authors, such as Gunther et al. (2005), after subjecting three groups of subjects to a treatment with different calcium content $(800,1000$, and $1300 \mathrm{mg} \mathrm{Ca} /$ day respectively), no significant differences in the body weight of the individuals were found. Lappe et al. (2004), after administering to groups of people a diet with different calcium content (900 vs $1500 \mathrm{mg} \mathrm{Ca} /$ day), did not notice any difference in the weight of the subjects neither. Snijder et al. (2007), after reviewing the data from the HOORM'S study, also found no association between body weight and calcium intake.

However, other publications show inconsistent results. Zemel et al. (2000), after conducting a study in rats, concluded that high calcium diets reduced weight gain. Metz et al. (1988) pointed out that, after subjecting Wistar Kyoto rats to a normocaloric treatment with high calcium content ( $4 \mathrm{~g} / \mathrm{kg}$ feed) for eleven weeks, they also found an association between the high level of calcium in the diet and the reduction in the animals' body weight. González et al. (2013) worked with adults from 20 to 59 years of age, where they concluded that there is an inverse association between dietary calcium intake and high body mass index.

\subsubsection{Calcium content in rodents}

According to the results obtained from the variance analysis regarding the calcium content, there was a significant difference $(\mathrm{p}<0.05)$. This shows that not all the averages of the set out groups are equal.

When there was a significant difference, the respective Tukey significance tests for treatments were performed, which indicate us the similarities and differences and help us select the best treatment statistically. 
Table 3. Calcium content of experimental

\begin{tabular}{|c|c|}
\hline $\begin{array}{c}\text { Experimental } \\
\text { group }\end{array}$ & $\begin{array}{c}\text { Calcium content } \\
(\mathbf{g} / \mathbf{1 0 0} \mathbf{~ g})\end{array}$ \\
\hline GB & $1119.02^{\mathrm{b}}$ \\
\hline GE10 & $1251.53^{\mathrm{a}}$ \\
\hline GE15 & $1224.95^{\mathrm{a}}$ \\
\hline GE 20 & $1195.99^{\mathrm{ab}}$ \\
\hline
\end{tabular}

Values are average of triplicate analysis. The different letters in the same row indicate significant differences $P$ $<0.05$ between the variants

The best results are shown by GE10 with a diet of $29.94 \mathrm{mg} \mathrm{Ca} / \mathrm{g}$ of the F1 product (bread with $10 \%$ replacement). It shows a significantly higher calcium content compared to the white group (GB) that had a diet based on a bakery product with traditional formulation $(\mathrm{F} 0)$.

\subsubsection{Calcium Assimilation}

After 2 weeks of adaptation and before starting the experiment, the analysis of calcium content in the standard group (GP) was performed giving an average value of 1146.15 $\mathrm{mg} \mathrm{Ca} / 100 \mathrm{~g}$. This value shows us the initial conditions of the experimental units, that way we can know the mineral assimilation for each group.

The assimilation of calcium from the different formulations for making the bread with partial replacement of wheat flour with eggshell powder (F1, F2 and F3) and a traditional formulation (F0), was determined according to the content of initial calcium (GP).

Table 4. Calcium Assimilation

\begin{tabular}{|l|c|c|c|}
\hline \multirow{2}{*}{ Groups } & \multicolumn{2}{|c|}{$\begin{array}{c}\text { Calcium content } \\
(\mathbf{m g} / \mathbf{1 0 0 g})\end{array}$} & \multirow{2}{*}{$\begin{array}{c}\text { Assimilation } \\
\text { \% }\end{array}$} \\
\cline { 2 - 3 } & Initial & Final & \\
\hline GB & 1146.15 & 1119.02 & -2.37 \\
\hline GE10 & 1146.15 & 1251.53 & 9.19 \\
\hline GE15 & 1146.15 & 1224.95 & 6.87 \\
\hline GE20 & 1146.15 & 1195.99 & 4.35 \\
\hline
\end{tabular}

In table 4 it is shown that the experimental groups that had a diet based on bread with eggshell powder increased the calcium content, obtaining an assimilation of $9.19 \%, 6.87 \%$ and $4.35 \%$ for groups GE10, GE15 and GE20 respectively. However, the opposite is true regarding the white group (GB) where the assimilation was negative $(-2.37 \%)$.

The white group (GB) presents a loss of calcium with a decrease of $2.37 \%$. This is due to the change of diet of $11.52 \mathrm{mg} \mathrm{Ca} / \mathrm{g}$ of the feed to a diet based on bread with traditional formulation with a calcium content of $0.33 \mathrm{mg}$ $\mathrm{Ca} / 100 \mathrm{~g}$, causing bone resorption.

In addition, GE10 has a greater assimilation of calcium after having changed from a feed diet to a diet with $29.94 \mathrm{mg} \mathrm{Ca} / \mathrm{g}$ of bread with partial substitution of wheat flour with eggshell powder (10\%). Nevertheless, GE15 and GE20 have lower assimilations despite having a higher calcium content in the diets provided.

Malm (1958), Heaney et al. (1975), Oguido and De Angelis (1995) showed that the fraction of calcium absorbed by the diet is inversely proportional to the amount ingested. This fact could be due to a delay in the disintegration of the mineral during intestinal transit (Milbradt et al. 2017).

Bao et al. (1998) studied the possibility of rats absorbing and using calcium from the fortified diet with different sources of calcium, within which eggshell powder was mentioned and then was revealed to have a very high absorption and utilization capacity.

In addition, Dutch and Japanese researchers reported that eggshell calcium has positive effects (Ali and Badawy, 2017).

In the same way, Schaafsma et al. (2002); Rovenský et al. (2003); Brun et al. (2013) and Fina et al. (2016) showed in humans that a calcium supplementation from eggshell powder has a positive effect with an adequate intake of this mineral. 


\subsection{Optimal product analysis}

\subsubsection{Proximate Composition}

In table 5, bread with partial substitution of wheat flour with eggshell powder in $10 \%(\mathrm{~F} 1)$ has $23.80 \%$ moisture. This value is within the parameters indicated in the Sanitary Standard for Manufacture, Processing and Expenditure of Bakery, Biscuit and Pastry Products RM No. 1020-2010 / MINSA, which indicates that common or tilled bread must contain a moisture of $23 \%$ (min.) - $35 \%$ (max.).

On the other hand, the ash content is $5.24 \%$. This is due to the amount of minerals that eggshell powder contains. Ray et al. (2017) made chocolate cake using eggshell powder, in which they found that a substitution of $9 \%$ contained $5.5 \%$ of ashes.

Table 5. Proximate Composition of bread with $10 \%$ substitution

\begin{tabular}{|l|c|c|}
\hline Analysis & Unity & Results \\
\hline Moisture & $\%$ & 23.80 \\
\hline Ash & $\%$ & 5.24 \\
\hline Fat & $\%$ & 3.83 \\
\hline Protein & $\%$ & 9.25 \\
\hline Fiber & $\%$ & 2.10 \\
\hline Carbohydrates & $\%$ & 55.78 \\
\hline Energy & KJ & 295.79 \\
\hline
\end{tabular}

According to the National Institute of Health (INS, 2009), tilled bread contains $9.60 \%$ proteins, $0.3 \%$ total fat, $71.8 \%$ total carbohydrates, $1.2 \%$ crude fiber and $328 \mathrm{KJ}$ energy. According to the results shown in table 5, the Proximate Composition of the product is greater regarding the fat and fiber content. However, it is lower regarding the protein, carbohydrate and energy content.

\subsubsection{Microbiological analysis}

Table 6 shows that the mold count is less than 10 in CFU / g. This parameter is permissible according to the Sanitary Standard for the Manufacture, Processing and Expenditure of Bakery, Biscuit and Pastry Products R.M. N ${ }^{\circ}$ 1020-2010 / MINSA.

Table 6. Microbiological analysis of bread with $10 \%$ substitution

\begin{tabular}{|c|c|c|}
\hline Determination & Results & Units \\
\hline Molds & $<10$ & $\mathrm{UFC} / \mathrm{g}$ \\
\hline
\end{tabular}

Note: UFC $=$ Colony forming units

\subsubsection{Calcium content in bread}

Table 7 shows the calcium content in the optimal product, resulting in $29.47 \mathrm{mg} / \mathrm{g}$. This result is in line with Ali and Badawy (2017), who mentioned that increasing the content of eggshell powder in bread strips, increases the calcium content in comparison to a control sample. In the substitution at $10 \%$ they found a calcium content of $30.78 \mathrm{mg} / \mathrm{g}$ of bread.

Table 7. Calcium content of bread with $10 \%$ substitution

\begin{tabular}{|c|c|c|}
\hline Analysis & Results & Unity \\
\hline Calcium & 29.47 & $\mathrm{mg} / \mathrm{g}$ \\
\hline
\end{tabular}

Each bread weighs around 40 grams. Therefore the calcium content is $1178.95 \mathrm{mg} /$ unit of bread.

However, INS (2009), in the Peruvian Food Composition Tables, indicate that the calcium content of tilled bread is $0.4 \mathrm{mg} / \mathrm{g}$ of the food. The content of this mineral in the final product has a high value compared to that written by the National Institute of Health, this is because of the high ash content in eggshell powder which mostly comes from calcium carbonate $(\mathrm{CaCO} 3)$.

Piscoya C. (2002) mentions that calcium carbonate is a food additive that has greater advantages over others, such as citrate and acetate, since carbonate has a higher percentage of elemental calcium (40.04\%), has low cost and Food Codex indicates its conditions of use.

Most studies agree on the need to maintain a high calcium intake in adolescence, as a dairy diet, fortified foods or medicated supplements, because the only modifiable determinants of 
bone mass peak are exogenous (Sánchez et al., 2003).

\section{Conclusions}

According to the results, the formulation of bread with partial substitution of wheat flour (HT) with eggshell powder $(\mathrm{HCH})$ at $10 \%(\mathrm{~F} 1)$ has the highest calcium assimilation compared to bread with conventional formulation (F0). It is worth mentioning that this product rich in calcium and generated from an organic residue would contribute to solve calcium deficit in the body.

\section{References}

Alais, C., Linden, G., \& Fuentes, A. M. (1990). Manual de bioquímica de los alimentos. Barcelona: Masson.

Ali, M., \& Badawy, W. Z. (2017). Utilization of Eggshells By-Product as A Mineral Source for Fortification of Bread Strips. Journal Food and Dairy Science , 8(11), 455-459.

AOAC. 2.173 Ash determination method.

AOAC 31.043 (1980). Carbohydrates determination method.

AOAC - ISO 1871-1975. (1980). Proteins determination method 2.057.

Bao, S. F., Windisch, W., \& Kirchgessner, M. (1998). Calcium bioavailability of different organic and inorganic dietary-calcium sources (citrate, lactate, acetate, oyster-shell, eggshell, beta-tri-calcium phosphate). Journal Animal. Physiology - and Animal Nutrition, 78(3), 154-160.

Bartter, J., Diffey, H., Yeung, Y. H., O'Leary, F., Hasler, B., Maulaga, W., și alții. (2018). Use of chicken eggshell to improve dietary calcium intake in rural sub-Saharan Africa. Maternal \& Child Nutrition, 14(S3), 1-10.

Brun, L. R., Lupo, M., Delorenzi, D. A., Di Loreto, V. E., \& Rigalli, A. (2013). Chicken eggshell as suitable calcium source at home. International Journal Food Science Nutrition , 64(6), 1-4.

Fina, B. L., Brun, L. R., \& Rigalli, A. (2016). Increase of calcium and reduction of lactose concentration in milk by treatment with kefir grains and eggshell. International Journal Food Science Nutrition, 67, 133-140.

Fuentes, F., Mendoza, R., Rosales, A., Cisneros, R., (Perú), I. N., \& Salud, P. M. (2008). Guía de manejo y cuidado de animales de laboratorio: Ratón. Lima: Centro de Información y documentación Cientifica del INS.

Gómez, D. L. (2011). Cuantificación de Calcio en soluciones caseras que contienen cáscara pulverizada de huevo de gallina (Gallus gallus). Guatemala.

Gonzáles, A., Campos, I., Hernández, L., \& Flores, M. (2013). Asociacion entre la ingesta de calcio dietetico y el indice de masa corporal elevado en adultos. Revista Biomédica MedWave, 13(2), 1-11.

Gunther, C. W., Legowski, P. A., Lyle, R. M., McCabe, G. P., Eagan, M. S., Peacock, M., și alții. (2005). Dairy products do not lead to alterations in body weight and fat mass in young women in a one year intervention. American Journal of Clinical Nutrition, 81(4), 751-756.

Heaney, R. P., Saville, P. D., \& Recher, R. R. (1975). Calcium absorption as a function of calcium intake. Journal of Laboratory and Clinical Medicine , 85, 881-890.

Instituto Nacional de Salud (INS). (2009). Tablas peruanas de composición de alimentos. Lima, Perú: Ministerio de Salud, Instituto Nacional de Salud.

Isserliyska, D., Karadjov, G., \& Angelov, A. (2001). Mineral compositions of Bulgarian wheat bread. European Food Research and Technology, 213(3), 244-245.

Keller, J., Lanou, A., \& Barnard, N. (2002). The consumer cost of calcium from food ans suplements. Journal of the Academy of Nutrition and Dietetics , 1669-1671.

Kessenich, C. R. (2008, January). Alternative choices for calcium supplementation. 4, 3639.

Lappe, J. M., Rafferty, K. A., Davies, K. M., \& Lypaczewski, G. (2004). Girls on a highcalcium diet gain weight at the same rate as girls on a normal diet: A pilot study. 
Journal of the Academy of Nutrition and Dietetics , 1361-1367.

Malm, O. J. (1958). Calcium requirement and adaptation in adult men. Scandinavian Journal of Clinical and Laboratory Investigation, 10(36), 1.

Metz, J. A., Karanja, N., Torok, J., \& McCarron, D. A. (1988). Modification of total body fat spontaneously hypertensive rats and wistarkyoto rats by dietary calcium and sodium, 1(1), 58-60.

Milbradt, B. G., da Silva, J. S., Silveira, A. S., Dutra, L. O., Pereira, R. D., Callegaro, M. D., și alții. (2017). Eggshell fractions containing different particle sized affect mineral absorption but not bone mineral retention in growing rats. International Journal of Food Sciences and Nutrition, 68(2), 210-218.

MINSA. (2010). Norma Sanitaria para la Fabricación, Elaboración y Expendio de Productos de Panificación, Galletería y Pastelería, R.M. No 1020-2010/MINSA.

Nollet, L., \& Toldrá, F. (2012). Handbook of Analysis of Active Compounds in Functional Foods (Vol. II). Estados Unidos: Taylor \& Francis Group.

NTP 209.085:1981 (review 2017). Gelatinas. Determination of humidity.

NTP 209.093. Determination of the ether extract (crude fat).

NTP 209.074:1974 (review 2013). Fiber by the method. Starches. Determination of soluble.

Obrego, A., Contreras, E., Muñoz, A., Ayquipa, R., \& Fernandez, W. (2013). Evaluación sensorial y fisicoquimica de panes con sustitución parcial de la harina de trigo (Triticum aestivum) por harina de maiz (Zea Mays) y papa (Solanum Tuberosum). Ciencia e Investigación.

Oguido, A. K., \& De Angelis, R. C. (1995). Cinética de absorção do cálcio do leite e casca de ovo no intestino delgado de ratos. . Agrárias Londrina , 16(1), 7-13.

Piscoya, C. (2002). Formulación, elaboración y prueba de aceptabilidad de pan francés fortificado con calcio en dos concentraciones. Lima -Perú.
Ray, S., Barman, A. K., Roy, P. K., \& Singh, B. K. (2017). Chicken eggshell powder as dietary calcium source in chocolate cakes. The Pharma Innovation Journal , 6(9), 0104.

Rovenský, J., Stancíková, M., Masaryk, P., Svík, K., \& Istok, R. (2003). Eggshell calcium in the prevention and treatmment of osteoporosis. International Journal of Clinical Pharmacology Research , 23((2/3)), 83-92.

Sánchez, A., Puche, R., Zeni, S., Oliveri, B., Galich, A., Maffei, L., et al. (2003). Papel del calcio y de la vitamina $D$ en la salud ósea (Parte I). Elsevier .

Schaafsma, A., Van Doormaal, J. J., Muskiet, F. A., Hofstede, G. J., Pakan, I., \& Van der Veer, E. (2000). Mineral, amino acid, and hormonal composition of chicken eggshell powder and the evaluation of its use in human nutrition. Poultry Science, 79(12), 1833-1838.

Schaafsma, Z., Van Doormal, J. J., Muskiet, F. A., Hofstede, G. J., Pakan, I., \& Van Der Veer, E. (2002). Positive effects of a chicken eggshell powder-enriched vitamin-mineral supplement on femoral neck bone mineral density in healthy late post-menopausal Dutch women. British Journal of Nutrition ,87, 267-275.

Servicio de Experimentación Animal. (2005). Eutanasia (rata, raton, hamster y cobayo). Universidad de Salamanca. Salamanca: S.E.A. Animalario OMG.

Snijder, M. B., Van Der Heijden, A. A., Van Dam, R. M., Stehouwer, C. D., Hiddink, G. J., Nijpels, G., și alții. (2007). Is higher dairy consumption associated with lower body weight and fewer metabolic disturbances? TheHoorn Study. The American Journal of Clinical Nutrition, 85(4), 989-995.

Valdés, J. (2009). Seminario Internacional sobre Nutricion de Huevo. Rev Cubana de Alimentación y Nutrición , 19(1), 84-102.

Zemel, M. B., Shi, H., Greer, B., Dirienzo, D., \& Zemel, P. C. (2000). Regulation of adiposity by dietary calcium, The FASEB Journal , 14(9), 1132-1138. 


\section{Acknowledgment}

The authors express their sincere gratitude to "Universidad Nacional de San Agustín de Arequipa" for the financial support to conduct this research work (No. Project $N^{\circ}$ TP-0582018-UNSA). They also express their gratitude for the support and advice of Dr. Franklin, Dr. Mario Carhuapoma Yance, Mg. Luis Medina Marroquin. 